\title{
Microbial-derived bio-surfactant using neem oil as substrate and its suitability for enhanced oil recovery
}

\author{
Temitope Ogunkunle ${ }^{1} \cdot$ Adesina Fadairo $^{1,2} \cdot$ Vamegh Rasouli $^{2} \cdot$ Kegang Ling $^{2} \cdot$ Adebowale Oladepo $^{1}$. \\ Onyinyechi Chukwuma ${ }^{1}$. James Ayoo ${ }^{3}$
}

Received: 7 July 2020 / Accepted: 5 November 2020 / Published online: 23 November 2020

(C) The Author(s) 2020

\begin{abstract}
The limitation in the formulation and application of synthetic surfactants in petroleum industry is owing to their high cost of production or importation and their associated toxic effect which have been proven to be harmful to the environment. Hence it is vitally imperative to develop an optimum surfactant that is cost-effective, environmentally safe (biodegradable) and equally serves as surface acting agent. This study discusses the production of microbial produced bio-surfactant and its application in enhanced oil recovery. The bacteria Pseudomonas sp. were isolated from urine and allow to feed on neem seed oil as the major carbon source and energy. The crude bio-surfactant produced from the fermentation process was used to prepare three (3) solutions of bio-surfactants at different concentrations of $5 \mathrm{~g} / 500 \mathrm{~mL}, 10 \mathrm{~g} / 500 \mathrm{~mL}$ and $15 \mathrm{~g} / 500 \mathrm{~mL}$, and their suitability for enhanced oil recovery (EOR) was evaluated. Reservoir core samples and crude oil collected from the Niger Delta field were used to evaluate the EOR application of the microbial-derived surfactants. The sets of experimental samples were carried out using core flooding and permeability tester equipment, and the results obtained were compared with conventional waterflooding experiments. The three bio-surfactant concentrations were observed to recover more oil than the conventional waterflooding method for the two core samples used. Optimum performance of the produced microbialderived surfactant on oil recovery based on the concentrations was observed to be $10 \mathrm{~g} / 500 \mathrm{~mL}$ for the two samples used in this study. Therefore, eco-friendly bio-surfactant produced from neem seed oil using Pseudomonas sp. has shown to be a promising potential substance for enhanced oil recovery applications by incremental recoveries of $51.9 \%, 53.2 \%$, and $29.5 \%$ at the concentration of 5,10 , and $15 \mathrm{~g} / 500 \mathrm{~mL}$ and $24.7 \%, 28.7 \%$, and $20.1 \%$ at concentration of 5,10 , and $15 \mathrm{~g} / 500 \mathrm{~mL}$ for the two core samples, respectively.
\end{abstract}

Keywords Microbial derived bio-surfactant $\cdot$ Neem oil $\cdot$ Enhanced oil recovery $\cdot$ Pseudomonas sp. $\cdot$ Bio-degradable

\section{Introduction}

Crude oil as a major energy source continues to be highly demanding, and this necessitates the oil and gas industry to explore every possible technology that is economically feasible to maximize the recovery of the field and maintain a balance in oil price (Oladepo et al. 2017, Sandersen et al.

Adesina Fadairo

adesinafadairo@yahoo.com

1 Department of Petroleum Engineering, Covenant University, Ota, Nigeria

2 Department of Petroleum Engineering, University of North Dakota, Grand Forks, USA

3 Chevron Nigeria Limited, Lagos, Nigeria
2012; Gao and Zekri 2011). This is because as more production is carried out as a result of the increasing demand for energy, the reservoir's primary energy is depleted having produced about $20-30 \%$ of the reserve leaving about $70 \%$ of the estimated oil recovery. Enhanced oil recovery method is a technology mostly employed in oilfields that have exhausted the primary (using the natural reservoir drive energy) and secondary recover method (waterflooding or gas flooding), to improve the productivity of the field. This technology over the years has been improved and can be realized using methods like microbial injection or thermal recovery, chemical injection, gas injection, and ultrasonic stimulation. Chemical enhanced oil recovery among others has received attention in the recent research because of its ability to improve the microscopic displacement efficiency through various mechanisms like

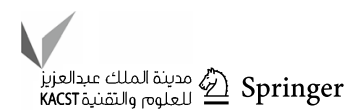


wettability alteration, change in fluid physical properties, gravity drainage, and reduction in the interfacial tension (Gusmão et al. 2010; Desai and Banat 1997; Gao et al. 2016). Among the chemical enhanced oil recovery process, polymer and surfactant flooding is receiving much consideration simply because of its potency in extracting residual oil by primary and secondary recovery methods (Fadairo et al. 2018). Surfactants are chemical compounds that are used in cosmetics, detergent and textile industry but in the recent time have been embraced in the oil and gas industry due to their capacity to lessen boundary forces (surface and interfacial tensions) that exist between the liquid phase (injected water) and the trap reservoir fluid (oil) within the reservoir to a negligible value (Ultralow). Generally, surfactants have a peculiar molecular structure known as an amphipathic structure, which means, it contains both a lyophobic group that has a very small attraction for solvent and another group (lyophilic group) with a strong attraction for solvent. When we dissolve surfactant in a solvent such as water, the hydrophobic group (lyophobic) within the surfactant alters the molecular arrangement of the water molecule by distorting the hydrogen bonds within it. To this end, part of the surfactant molecules will be expelled to the boundaries (interfaces) and their hydrophobic groups situated to limit the contact with the water molecules. Therefore, the water surface becomes a single layer of surfactant molecule, and their hydrophobic groups oriented toward the outer boundary. The effectiveness of the surfactant is determined by its ability to reduce the interfacial tension that exists between the recoverable crude oil left in the reservoir and the injection fluid (Fadairo et al. 2019; Geetha et al. 2018). Surfactant can be prepared chemically (chemical surfactant) and biologically (bio-surfactants) (Torres et al. 2011). Chemical surfactant is used in the petroleum industry to increase field recovery of hydrocarbon from brown or green fields (Saxena et al. 2017). These surfactants are not biodegradable and so can be very harmful to the environment, while biologically prepared surfactants are ecofriendly and have shown corresponding emulsification properties and are biodegradable (Bordoloi and Konwar 2008; Al-Bahry et al. 2013; Banat 1995; Batista et al. 2010; Chai et al. 2015). Recently much attention has been given to bio-surfactant owning to its relative advantages as compared to chemical synthesis. These advantages include higher biodegradability, lower toxicity, and improved environmental compatibility, high selectivity, higher foaming, specific activity at elevated temperature, salinity, and $\mathrm{pH}$, and the ease of being able to be produced from renewable materials (Fadairo et al. 2019; Chaprão et al. 2015; Ojo and Fadairo 2017). For the use in enhanced oil recovery, the following are examples of bio-surfactant that has been studied: Rhamnolipids gotten from
Pseudomonas $s p$ (Tunio et al. 2011), and bio-surfactant produced by Bacillus lichenifirmis. Several studies have been reported on the use of surfactants in enhanced oil recovery applications. These include the work of Chaprão et al. (2015), which evaluated the applicability of bacterial and yeast bio-surfactants for enhanced removal and biodegradation of engine oil from contaminated sand. The results of two chemically synthesized surfactants and two produced biodegradable surfactants through kinetic assay were examined. Three concentrations of the bio-surfactant were used, and upon increasing the concentration of biosurfactant, there was no sign of any toxicity on the native microbial population in the soil (the produced bio-surfactant is environmentally friendly). It was observed that bio-surfactant produced from Bacillus sp. was not as effective as the bio-surfactant produced using $C$. sphaerica. The application of deep eutectic solvents and their constituents as oil field enhanced oil recovery surfactants was reported by Hadj-Kali et al. (2015). Torres et al. (2011) compared the performance of bio-surfactant and synthetic surfactants in enhanced oil recovery applications. The basis for their comparison was centered around the presence or absence of salinity up to $4.7 \%$ and their room temperature surface tension. The evaluation was conducted to see if the two surfactants could withstand reservoir conditions of temperature and salinity up to $75{ }^{\circ} \mathrm{C}$ and $5 \%$, respectively. The produced bio-surfactant exhibits characteristics and promising potentials better than the chemical synthesis surfactants. Pereira et al. (2013) reported biosurfactant produced by Bacillus subtilis optimization and enhanced oil recovery applications. The produced biosurfactants were produced by Bacillus bacteria and characterized using proton nuclear magnetic resonance, Fourier transform infrared spectroscopy, and matrix-assisted laser desorption ionization-time of flight mass spectrometry. Their results claimed a better performance of produced bio-surfactants than their chemical synthesis counterparts in enhanced oil recovery applications. Microbial enhanced oil recovery, production, and possible oil field applications were reported by Geetha et al. (2018). The highlights of the study were the potential use of microbial or bio-surfactants produced from waste in enhanced oil recovery of hydrocarbon. The methods explored involve either direct injection of bio-surfactant producing microorganisms or injection of already produced bio-surfactant into the well. Limited studies have been reported on the use of non-edible biodegradable seed oil as the main energy source for use in the production of bio-surfactants for enhanced oil recovery applications; however, it has been reported that non-edible seed oils with higher fatty composition are good carbon sources in the production of bio-surfactants (Al-Sulaimani et al. 2011; Batista et al. 2010; George and Jayachandran 2009). Therefore, this 
makes the need for research on the use of cost-effective, biodegradable, and non-edible seeds oil highly attractive and hence the current study. This work aims to develop bio-surfactants from non-edible seed oil (Neem seed oil) via microbial synthesis and evaluate their applicability as an additive for enhanced oil recovery. The microbial synthesis surfactant serves as an alternative for the conventional surfactant that chemically synthesized (chemical surfactant) in the petroleum industry. Two bacterial were examined for initial study based on reported literatures (Bacillus subtilis and Pseudomonas sp); however, the Bacillus subtilis was discontinued owing to low yield while Pseudomonas sp (Rhamnolipids) was subsequently used for the enhanced oil recovery applications.

\section{Experimentation}

\section{Materials}

Neem seed oil was procured from a local market in Lagos, Nigeria. Analytical grade chemicals such as benzene and chemical reagents (standard sodium carbonate ( 0.5 molar), hydrochloric acid ( 0.5 molar), alcoholic potassium hydroxide ( 0.5 molar solution in $96 \%$ ethanol), phenolphthalein indicator ( $1 \%$ solution in $96 \%$ ethanol), and sodium hydroxide were supplied by the chemistry laboratory within Covenant University, Ota, Nigeria. Core samples for the enhanced oil recovery application were obtained from oil wells within the Niger Delta environment, and the crude oil sample used was supplied by an indigenous oil company operating in the Niger Delta, Nigeria. The crude oil exhibits API gravity $36.6,0.842$ density, and viscosity of $2.5 \mathrm{cp}$ at $27^{\circ} \mathrm{C}$.

\section{Methods}

\section{Bio-surfactant production}

Considering the benefits of bio-surfactants produced by microorganisms, this study gave the description for the production and the characterization of a new bio-surfactant produced by Bacillus and Pseudomonias sp. (Rhamnolip$i d s$ ) that were isolated from male urine around Covenant University environment because of salinity stability. Typical average sea water salinity is around $35 \mathrm{~g} / \mathrm{L}$, oil and gas reservoirs have salinity between 30 and $90 \mathrm{~g} / \mathrm{L}$ depending on whether it is a sandstone or carbonate reservoir. However, urine salinity is between 40 and $220 \mathrm{~g} / \mathrm{L}$; this justifies the urine source for these organisms. Low yield of bio-surfactant formulated using Bacillus compared to Pseudomonias sp. (Rhamnolipids) was noticed after same incubation period.
Therefore, subsequent analyses were with Pseudomonias sp. (Rhamnolipids), since they are amphipathic in nature, that is comprising both hydrophilic and hydrophobic moieties that enable them to reduce surface and interfacial tension. The physicochemical properties of the seed oil and its bio-diesel are presented in Table 2, while the fatty acid composition of the seed oil and its percentages are presented in Table 3 . Neem seed oil contains a high percentage of oleic acid.

\section{Bacterial strain and preparation of seed culture}

A strain of Bacillus and Pseudomonas isolated from urine, belonging to the collection of the Department of Biological Sciences Covenant University was acquired. Sporulated cultures were obtained in Petri dishes with ISP-2 solid medium. The medium composed of $0.4 \%(\mathrm{v} / \mathrm{v})$ yeast extract, $1 \%(\mathrm{v} / \mathrm{v})$ malt extract and $2 \%(\mathrm{v} / \mathrm{v})$ agar, $\mathrm{pH} 7.0$, and it was incubated in a bacteriological incubator for 15 days at $30{ }^{\circ} \mathrm{C}$. The stock culture was kept in cryotubes with $10 \%$ (v/v) glycerol, undercooling at $-18{ }^{\circ} \mathrm{C}$. The microorganism was activated in ISP- 2 medium, modified by the absence of glucose according to George and Jayachandran (2009). The inoculum was obtained after culture in $1.0 \%(\mathrm{v} / \mathrm{v})$ malt extract and $0.4 \%(\mathrm{v} / \mathrm{v})$ yeast extract.

\section{Fermentation medium and bio-surfactant production}

Neem oil, bio-diesel, and glycerol were used as the carbon source to produce the bio-surfactant. (Neem oil bio-diesel was produced via the transesterification method.) A portion of the neem oil and the produced bio-diesel were tested for their physicochemical properties following ASTM and European committee for Standardization (ECN EN) specifications (ASTM D97 2002; ECN EN14214 2003; ASTM D6751 2009; ASTM D6371 2010). After this, the biosurfactants were formulated as follows. The liquid media aliquots for bio-surfactant production were prepared using a basal solution containing the following per liter: $4.5 \mathrm{~g}$ of $\mathrm{Na}_{2} \mathrm{HPO}_{4}, 0.68 \mathrm{~g}$ of $\mathrm{KH}_{2} \mathrm{PO}_{4}, 0.1 \mathrm{~g}$ of $\mathrm{MgSO}_{4} .7 \mathrm{H}_{2} \mathrm{O}, 6.5 \mathrm{~g}$ of $\mathrm{NaNO}_{3}, 0.5 \mathrm{~g}$ of yeast extract with $\mathrm{pH}$ of 6.5 and $30 \mathrm{~g}$ of glycerol. 3\% (10 g) of neem oil and neem oil bio-diesel substrates were used in place of glycerol in preparing other basal solution and were equally tested for bio-surfactant production using the earlier mention bacterial. After preparing the basal solution, the solution was autoclaved using an autoclave equipment by Astell Inc. The bacterial cell suspension of 1 optical density (OD) concentration in $0.9 \%$ saline solution was inoculated. After inoculation and thorough mixing, the solutions were incubated for $96 \mathrm{~h}$ at $37{ }^{\circ} \mathrm{C}$ under static conditions (George and Jayachandran 2009; Al-Sulaimani et al. 2011; Al-Wahaibi et al. 2014). After fermentation, the setup was centrifuged, the organic phase was evaporated to obtain the crude bio-surfactant in powdery form, and the

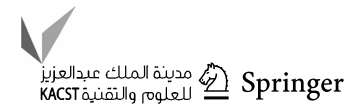


microbial pellet discarded. Out of the two samples (neem oil and neem oil bio-diesel substrates) prepared, it was discovered that the bio-surfactant produced using neem seed oil as the substrates yielded the best result, owing to its superior fatty components. Therefore, this was used for subsequent preparation of bio-surfactant solutions (George and Jayachandran 2009).

\section{Core flood experimental setup}

The core flood setup has been designed to drive toward fulfilling the application aspect of the research. The experimental setup which is to improve residual oil recovery and enhance oil production was done by analyzing how the oil recovery tends to respond to change in the interfacial tensions between the trapped oil and the injected surfactant solution, as well as the surfactant concentration. All experiments were performed at ambient conditions with differential pressure across the core holder being measured, each measurement carried out at an interval of $1 \mathrm{~min}$, and then continued for the rest of the flooding phase (Fig. 1).

Seven (7) bio-surfactant solutions (seven concentrations) were prepared for the enhanced oil recovery applications by dissolving a portion of the particulate bio-surfactant into a beaker containing deionized water of known volume as in Table 4. Before the core flooding experiment, the surface tension between the bio-surfactant solution and air was measured and the critical micelle concentration determined. The measured surface tension values at different concentrations of bio-surfactants are presented in
Table 5, and the critical micelle concentration was found to be around $10 \mathrm{~g} / 500 \mathrm{~mL}(0.02)$ which is very small but indicates its potential application for enhanced oil recovery. Therefore, 3 concentrations $(5 \mathrm{~g} / 500 \mathrm{~mL}, 10 \mathrm{~g} / 500 \mathrm{~mL}$ and $15 \mathrm{~g} / 500 \mathrm{~mL}$ ) were considered for the core flooding experiment. The three (3) bio-surfactant solutions were subjected to rheological properties evaluation using Ofite 800 Model viscometer manufactured by Ofite Testing Equipment Inc., USA, and results are presented in Fig. 2. The core samples were cleaned using n-hexane via a Soxhlet apparatus and dried at room temperature. Subsequently, the petrophysical properties of the cores were analyzed using a high-pressure core saturator manufactured by Vinci Equipment and presented in Table 1.

\section{Results and discussion}

The physicochemical properties of the seed oil and its bio-diesel are presented in Table 2, while the fatty acid composition of the seed oil and its percentages are presented in Table 3. The analyses of neem seed oil fatty acid show a high percentage of oleic and palmitic acids, about $70 \%$ are unsaturated, while around $30 \%$ are saturated free fatty acid. The high unsaturated acids imply less oxidation stability of the neem oil, which states why it is not edible. The reduction in density (Table 2) observed in the neem oil bio-diesel could be due to the two-stage esterification methods (transesterification); this has removed the large proportion of the contained fatty acid content, free

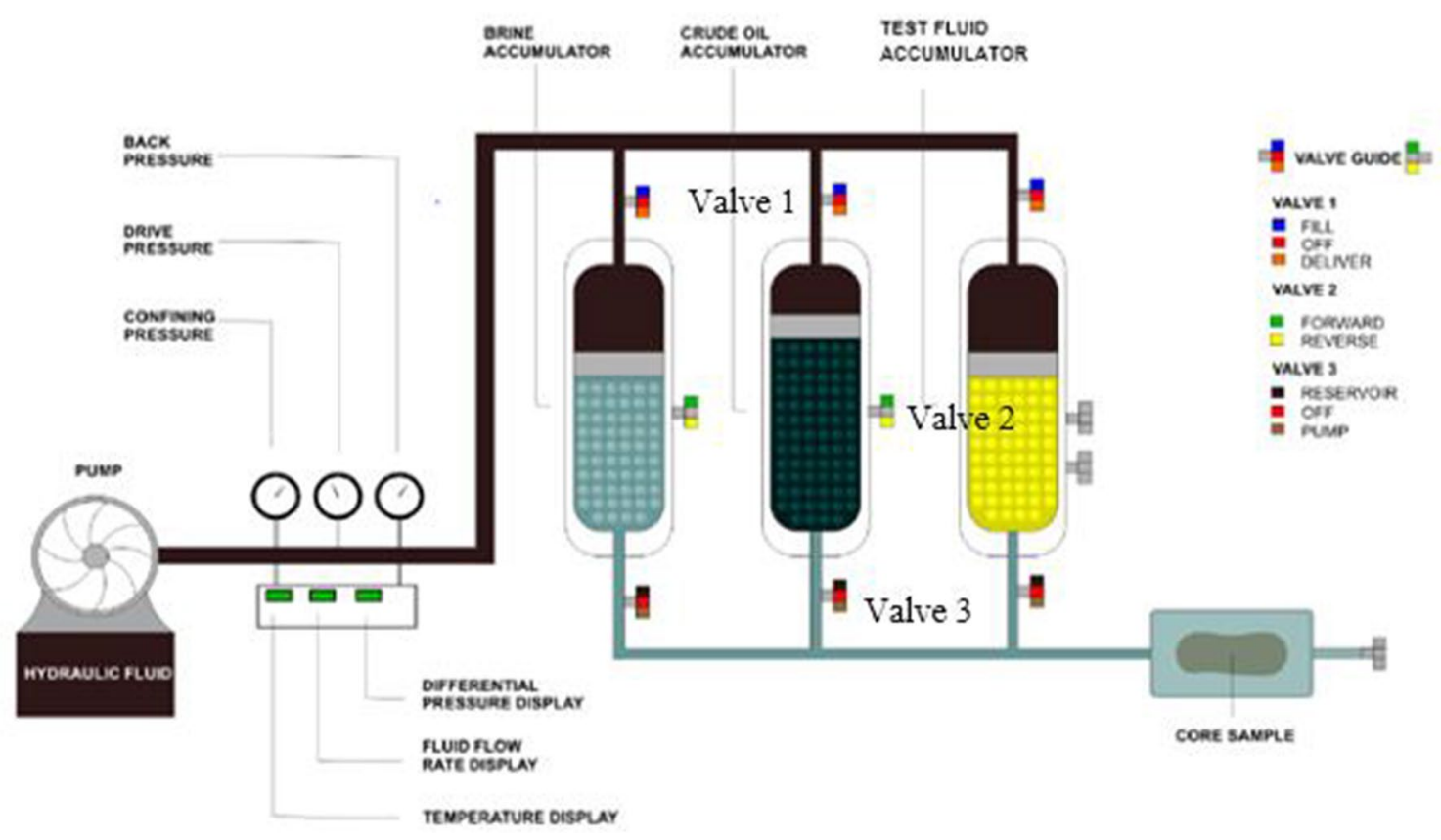

Fig. 1 Experimental core flood setup apparatus (David 2019)

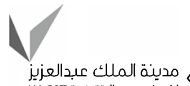

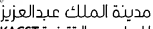
Springer 


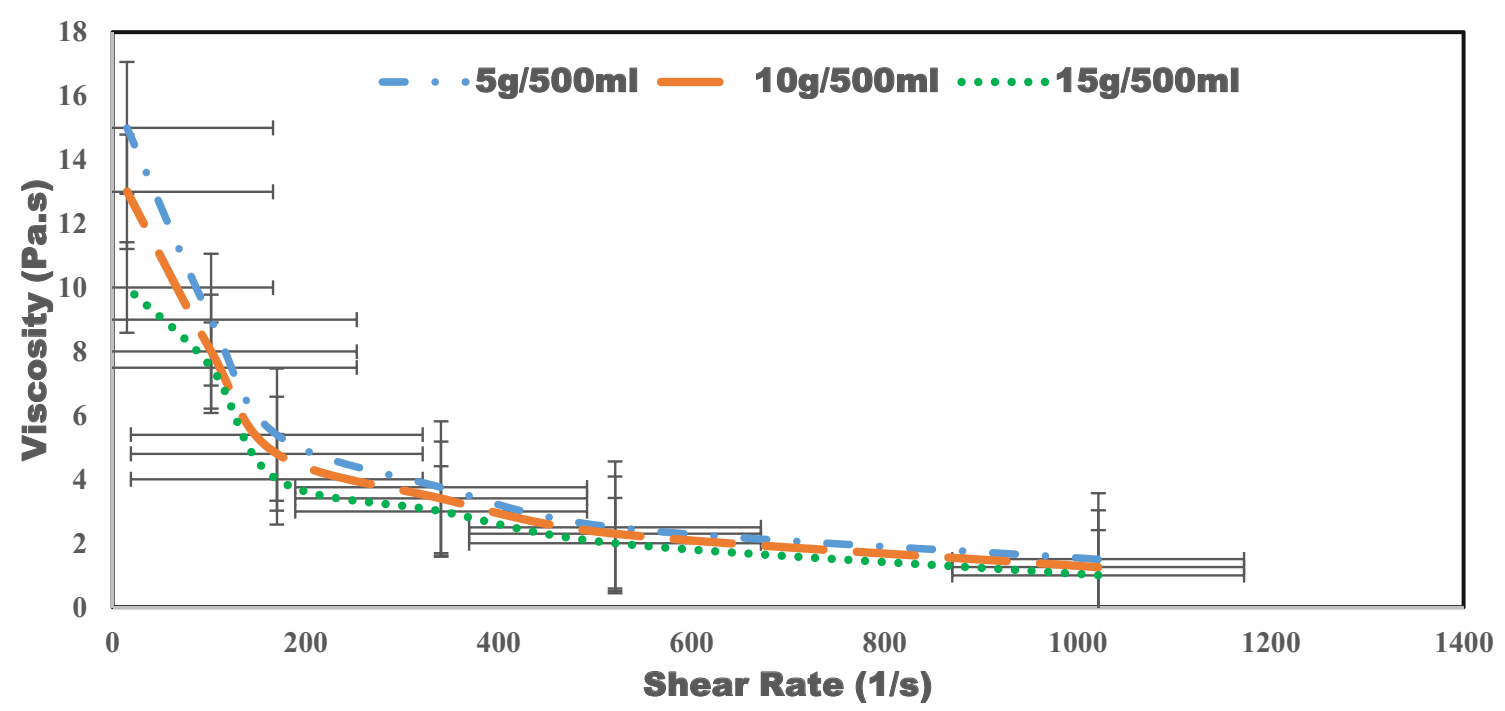

Fig. 2 Bio-surfactant solution viscosity

Table 1 Core properties

\begin{tabular}{lll}
\hline Properties & Core A & Core B \\
\hline Length $(\mathrm{cm})$ & 4.7 & 4.8 \\
Diameter $(\mathrm{cm})$ & 2.2 & 2.2 \\
Weight dried $(\mathrm{g})$ & 135.7 & 132.1 \\
Weight saturated $(\mathrm{g})$ & 157.5 & 152.9 \\
Bulk volume $\left(\mathrm{cm}^{3}\right)$ & 64.11 & 64.13 \\
Pore volume $\left(\mathrm{cm}^{3}\right)$ & 21.8 & 20.8 \\
Porosity & 0.335 & 0.324 \\
Permeability $(\mathrm{mD})$ & 234 & 189 \\
\hline
\end{tabular}

Table 2 Physicochemical characteristics of the neem seed oil

\begin{tabular}{lll}
\hline Characteristics & Neem oil & $\begin{array}{l}\text { Neem oil } \\
\text { bio-diesel }\end{array}$ \\
\hline Acid value $\left(\mathrm{mg} \cdot \mathrm{g}^{-1}\right)$ & 10.200 & 15.00 \\
Saponification value $\left(\mathrm{mg} \mathrm{g}^{-1}\right)$ & 200.00 & 178.00 \\
Cetane number & 84.3200 & 71.12 \\
Peroxide value $\left(\mathrm{meqO}_{2} \mathrm{Kg}^{-1}\right)$ & 1.4900 & 1.27 \\
Density at $27{ }^{\circ} \mathrm{C}$ & 0.91900 & 0.805 \\
Refractive index at $27{ }^{\circ} \mathrm{C}$ & 1.46500 & 1.325 \\
Viscosity at $27{ }^{\circ} \mathrm{C}$ & 47.7900 & 5.76 \\
Flash point $\left({ }^{\circ} \mathrm{C}\right)$ & 227.00 & 168 \\
Pour point $\left({ }^{\circ} \mathrm{C}\right)$ & 11.00 & - \\
Freezing point $\left({ }^{\circ} \mathrm{C}\right)$ & 10.00 & - \\
pH & 8.43 & 8.18 \\
\hline
\end{tabular}

and bound glycerin that was initially in the neem seed oil before bio-diesel conversion (Demirbas 2008). This can possibly explain why bio-surfactant production using
Table 3 Fatty acid composition of the neem seeds oil bio-diesel

\begin{tabular}{ll}
\hline Composition & $\%$ \\
\hline C16: Palmitic acid & $15.5 \pm 0.2700$ \\
C16: Palmitoleic acid & $0.12 \pm 0.0000$ \\
C18: 0Stearic acid & $18.7 \pm 0.4600$ \\
C18: 1 Oleic acid & $41.91 \pm 0.6900$ \\
C18: 2Linoleic acid & $19.59 \pm 0.4400$ \\
C20: 1Gadoleic acid & $1.33 \pm 0.0100$ \\
C20: 0Arachidic acid & $1.33 \pm 0.0100$ \\
C18: 3Linolenic acid & $0.44 \pm 0.0100$ \\
C22: 0Bhenic acid & $0.86 \pm 0.3800$ \\
Saturated fatty acids & 37.0000 \\
Unsaturated fatty acids & 63.0000 \\
\hline
\end{tabular}

Table 4 Bio-surfactant surface tension data

\begin{tabular}{lllll}
\hline S/N & $\begin{array}{l}\text { Surfactant/deion- } \\
\text { ized water ratio }\end{array}$ & $\begin{array}{l}\text { Bio-sur- } \\
\text { factant conc. }\end{array}$ & $\begin{array}{l}\text { Surface tension } \\
\text { (dynes/cm) }\end{array}$ & $\mathrm{pH}$ \\
\hline 1 & $0.5 \mathrm{~g} / \mathrm{mL}$ & 0.001 & 55.7 & 8.7 \\
2 & $1 \mathrm{~g} / \mathrm{mL}$ & 0.002 & 43.4 & 8.7 \\
3 & $2.5 \mathrm{~g} / 500 \mathrm{~mL}$ & 0.005 & 37.2 & 8.7 \\
4 & $4 \mathrm{~g} / 500 \mathrm{~mL}$ & 0.008 & 30.3 & 8.5 \\
5 & $5 \mathrm{~g} / 500 \mathrm{~mL}$ & 0.01 & 26.1 & 8.2 \\
6 & $10 \mathrm{~g} / 500 \mathrm{~mL}$ & 0.02 & 24.5 & 8.0 \\
7 & $15 \mathrm{~g} / 500 \mathrm{~mL}$ & 0.03 & 24.7 & 7.8 \\
\hline
\end{tabular}

neem seed oil bio-diesel as substrates yielded poor result, since most of the fatty component that should serve as an energy source for the microbes has been removed during esterification and why bio-surfactant produced from raw 
Table 5 Core sample saturation profile for core D

\begin{tabular}{lllllll}
\hline Samples & $\begin{array}{l}\text { Total pore volume of } \\
\text { the core }(\mathrm{cc})\end{array}$ & $\begin{array}{l}\text { Volume of water } \\
\text { expelled from core }(\mathrm{cc})\end{array}$ & $\begin{array}{l}\text { Total oil in } \\
\text { place }(\mathrm{cc})\end{array}$ & $\begin{array}{l}\text { Connate volume of } \\
\text { water }(\mathrm{cc})\end{array}$ & $\begin{array}{l}S_{\mathrm{o}}(\%) \\
S_{\mathrm{wc}}(\%)\end{array}$ & $\begin{array}{l}\text { Injection } \\
\text { rate }(\mathrm{cc} / \\
\mathrm{min})\end{array}$ \\
\hline $\mathrm{A}$ & 21.80 & 19.00 & 19.00 & 2.80 & 87 & 13 \\
$\mathrm{~B}$ & 20.80 & 16.70 & 16.7 & 4.10 & 80 & 17 \\
\hline
\end{tabular}

neem seed oil yielded better result. The neem oil and its bio-diesel exhibit refractive indices of 1.465 and 1.325 , respectively. Generally, refractive index values decrease with the molecular weight of the fatty acid components. Lower fatty acid molecular weight suggests higher saponification values since they are inversely proportional (Nwobi et al. 2006) (Table 4).

\section{Rheological behavior of the bio-surfactant concentration at room temperatures}

The viscosity results of the prepared bio-surfactant solutions were estimated from the deflection reading of the viscometer over the specified range of shear rate. Figure 2 presents the viscosity variation of the bio-surfactant solutions over the specified shear rates. The three concentrations analyzed exhibit a non-Newtonian behavior, specifically Bingham plastic behavior at room temperature. Because they are surface acting agents, the molecules are expelled to the interface of the bio-surfactant-air system (in the case of rheological property evaluation) and help worked on the frictional forces acting at the interface, thereby resisting flow compared to ordinary water. As can be observed from Fig. 2, surfactants, when present at low concentration in a system, have the property of adsorbing onto the surfaces or interfaces of the system and of altering to a noticeable degree the surface or interfacial free energies of those surfaces (or interfaces). This is better viscosity was observed in the low concentration bio-surfactant solutions $(5-10 \mathrm{~g} / 500 \mathrm{~mL})$.

\section{Core Flooding Results of Core}

In an attempt to evaluate the potential application of the formulated bio-surfactants by microbial strains for enhanced oil recovery applications from sandstone cores, several tests were conducted. As discussed earlier under Materials and methods section, the bio-surfactant solutions were used to displace oil from the cores in a tertiary flooding process. The results were compared with results from waterflooding. The three (3) concentrations of bio-surfactant used in evaluating its enhanced oil recovery performance are $5 \mathrm{~g} / 500 \mathrm{~mL}$, $10 \mathrm{~g} / 500 \mathrm{~mL}$, and $15 \mathrm{~g} / 500 \mathrm{~mL}$ of water. The recovery process was performed at room temperature of about $27^{\circ} \mathrm{C}$. The injection rate was maintained at about $3 \mathrm{cc} / \mathrm{min}$. The initial saturation profile of the core (Core A \& B) is presented in

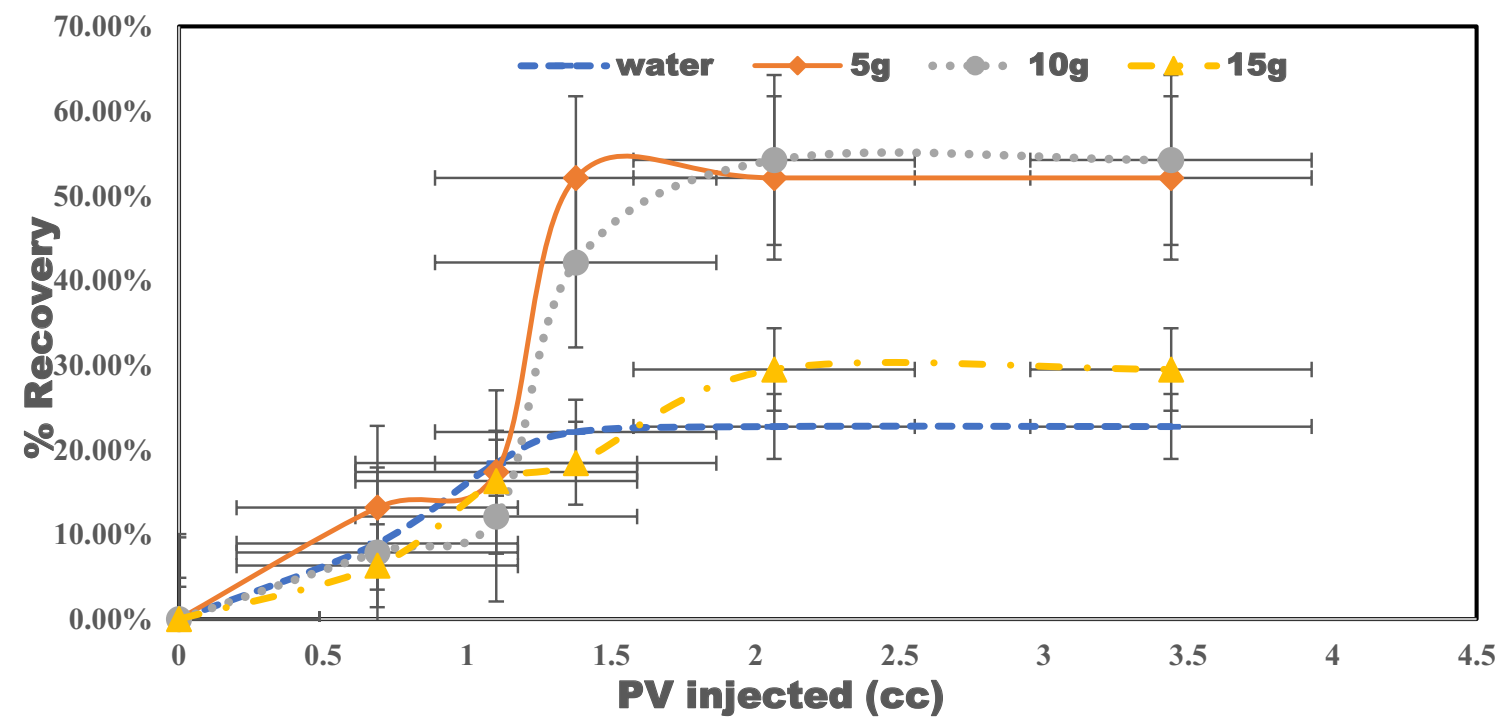

Fig. 3 Comparison of percentage recovery of different bio-surfactant concentrations tested and waterflooding scheme against pore volume injected for core A 


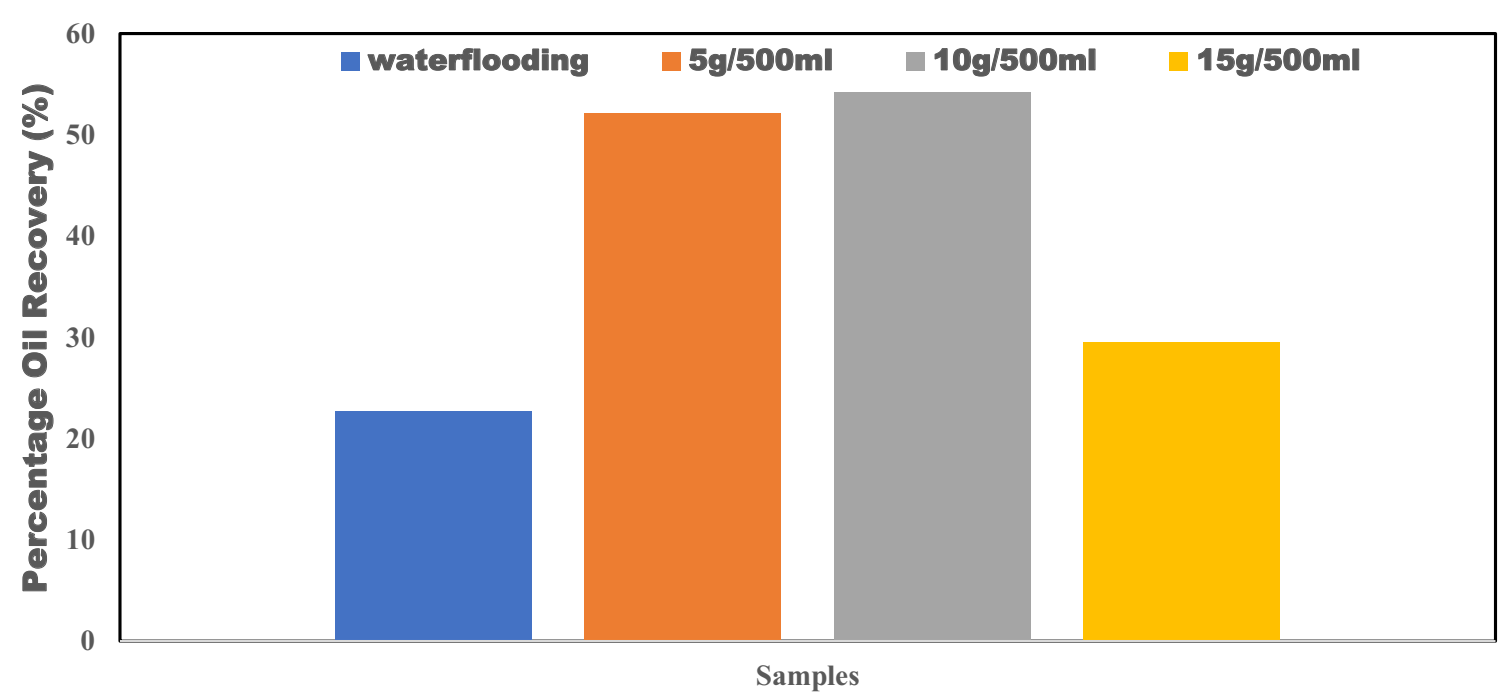

Fig. 4 Graphical evaluation of the performance of bio-surfactant concentrations compared to waterflooding for the flooding of core A

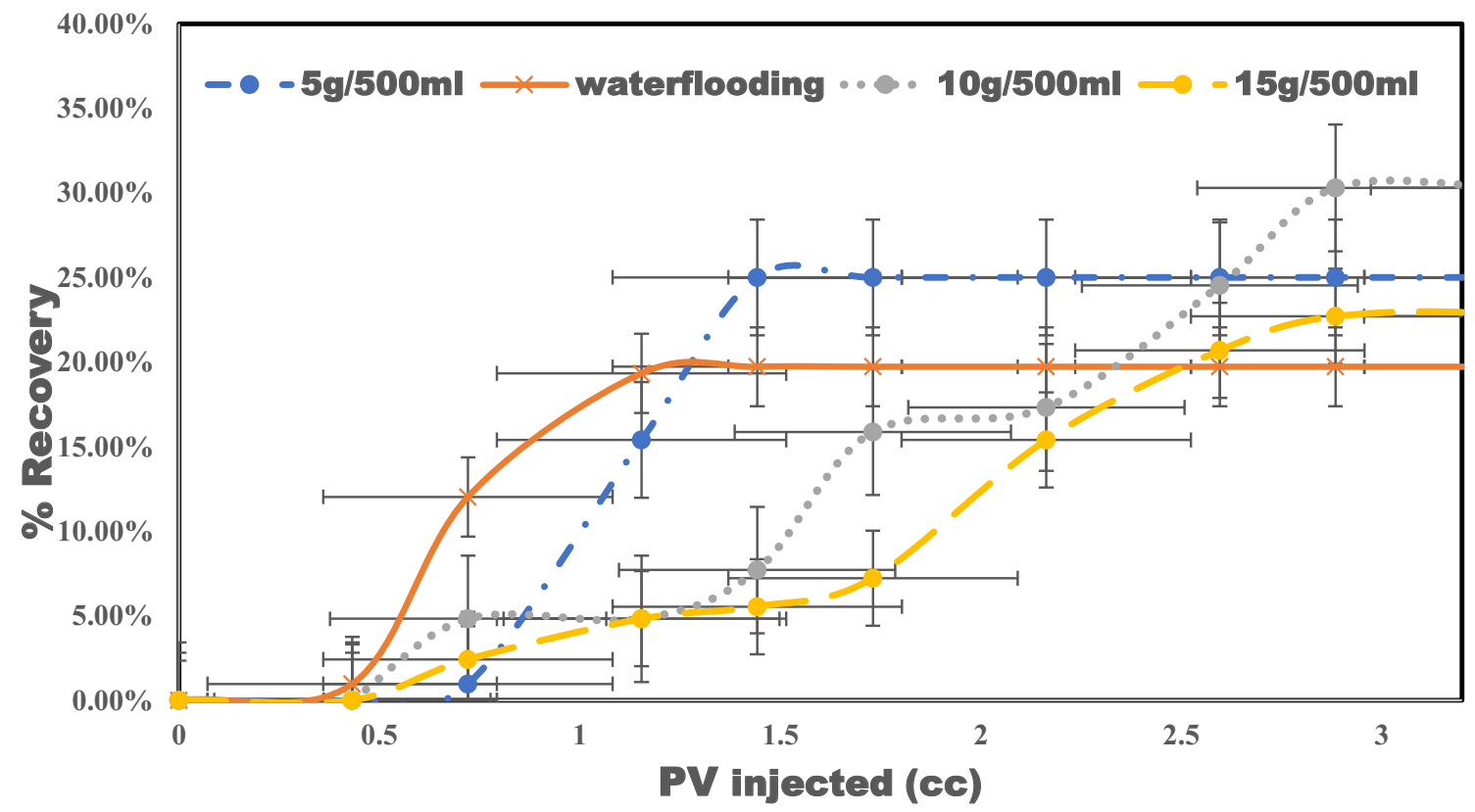

Fig. 5 Comparison of percentage recovery of different bio-surfactant concentrations tested and waterflooding scheme against pore volume injected for core B

Table 5. The performance evaluation was done by computing the percentage recovery from each of the concentrations with that of water at the same injection rate and pore volume injected. The results are presented in Figs. 3, 4, 5 and 6 for waterflooding and the three bio-surfactant concentrations injected, respectively. In each case, the effect of neem seed oil bio-surfactant concentration injected was compared with waterflooding.
The oil production is shown in Table 6. As seen in Table 6, a total of 8.67 pore volume water, Conc. 1, 2, and 3 bio-surfactant solutions flood into the core $\mathrm{A}$ at different runs, respectively, the breakthrough of water occurred for waterflooding after 0.69 pore volume of water has been injected. At this time, $1.7 \mathrm{cc}$ of residual oil had been produced. Waterflooding resulted in a recovery of $4.32 \mathrm{cc}$ of oil, which is about $22 \%$ of the initial oil in place (IOIP) (Fig. 4). The oil recovery at this stage was basically due to 


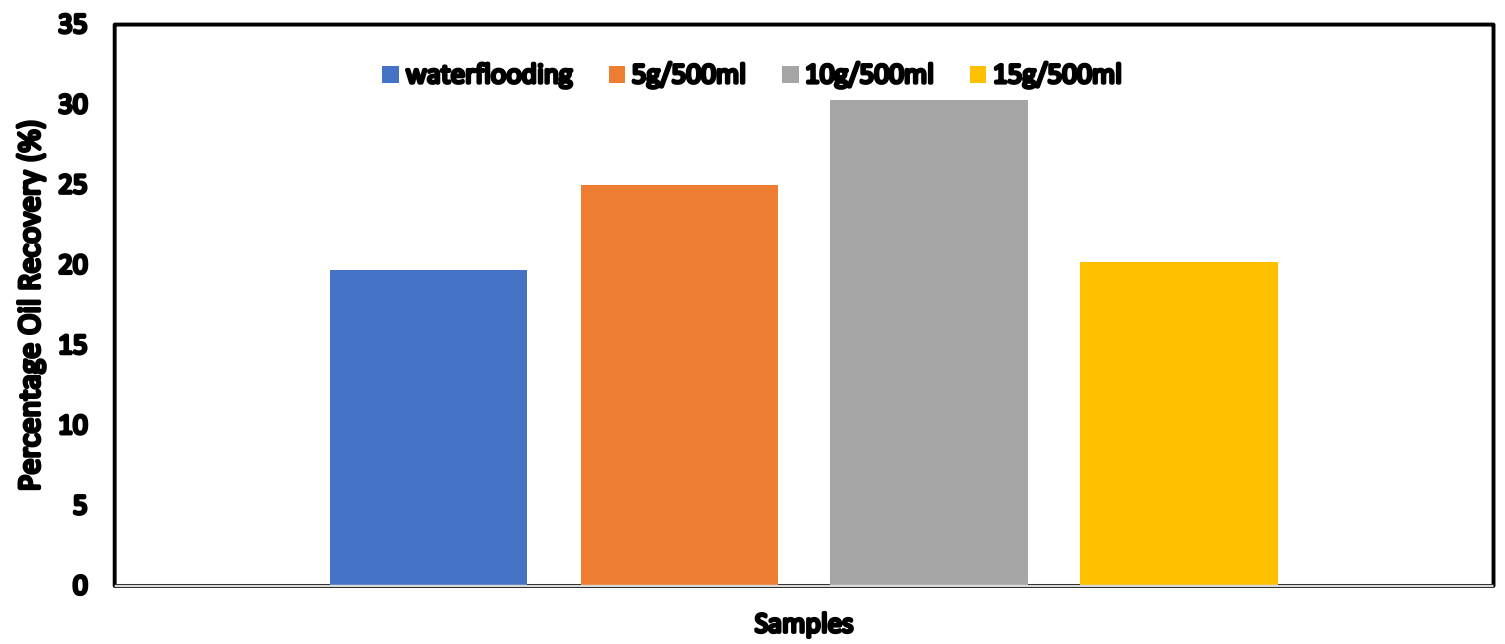

Fig. 6 Graphical evaluation of the performance of bio-surfactant concentrations compared to waterflooding for the flooding of core B

Table 6 Production of residual oil using ordinary waterflood and bio-surfactant solutions on core A

\begin{tabular}{|c|c|c|c|c|c|c|c|c|}
\hline \multirow[b]{2}{*}{$\begin{array}{l}\text { Pore Volume } \\
\text { Injected }\end{array}$} & \multicolumn{2}{|l|}{ Waterflood } & \multicolumn{2}{|l|}{ Conc. 1} & \multicolumn{2}{|l|}{ Conc. 2} & \multicolumn{2}{|l|}{ Conc. 3} \\
\hline & $\begin{array}{l}\text { Volume of } \\
\text { oil recovered/ } \\
\text { time (cc) }\end{array}$ & $\begin{array}{l}\text { Volume of } \\
\text { water recov- } \\
\text { ered/time (cc) }\end{array}$ & $\begin{array}{l}\text { Volume of } \\
\text { oil recovered/ } \\
\text { time (cc) }\end{array}$ & $\begin{array}{l}\text { Volume of } \\
\text { water recov- } \\
\text { ered/time (cc) }\end{array}$ & $\begin{array}{l}\text { Volume of } \\
\text { oil recovered/ } \\
\text { time (cc) }\end{array}$ & $\begin{array}{l}\text { Volume of } \\
\text { water recov- } \\
\text { ered/time (cc) }\end{array}$ & $\begin{array}{l}\text { Volume of } \\
\text { oil recovered/ } \\
\text { time (cc) }\end{array}$ & $\begin{array}{l}\text { Volume of } \\
\text { water recov- } \\
\text { ered/time (cc) }\end{array}$ \\
\hline 0 & 0 & 0 & 0 & 0 & 0 & 0 & 0 & 0 \\
\hline 0.688073 & 1.7 & 0 & 2.5 & 0 & 1.5 & 0 & 1.2 & 0 \\
\hline 1.100917 & 1.8 & 4.4 & 0.8 & 2.5 & 0.8 & 8.5 & 1.9 & 3.4 \\
\hline 1.376147 & 0.7 & 11.3 & 6.6 & 4.3 & 5.7 & 9.8 & 0.4 & 10.6 \\
\hline 2.06422 & 0.12 & 25.98 & 0 & 23.9 & 2.3 & 27.2 & 2.1 & 23.9 \\
\hline 3.440367 & 0 & 38.1 & 0 & 29 & 0 & 33.1 & 0 & 34.2 \\
\hline 8.669724 & 4.32 & & 9.9 & & 10.3 & & 5.6 & \\
\hline
\end{tabular}

the volumetric sweep efficiency that takes place by water injection (Al-Sulaimani et al. 2012). However, water injection was sustained until no more effluent oil was detected. Then, the core was removed, cleaned, and re-saturated to achieve initial condition before the first slug of the biosurfactant, concentration $1(5 \mathrm{~g} / 500 \mathrm{~mL})$ was injected. In this case, recovery oil was strictly due to a reduction in the interfacial tension between the bio-surfactant slugs and the trapped oil. Therefore, microscopic displacement of trapped oil (residual oil) was achieved. At the stage, the color of the effluent was different from the ones obtainable during waterflooding. The effluent color shows indications of dilution in the deep brownish color that was noticed during waterflood. This is an indication of some level of reduction in interfacial tension, as there is now miscibility between the residual oil and the bio-surfactant slug. As compared to waterflood, for Conc 1 (Table 4) of biosurfactant, oil recovery started after 0.69 pore volume has been injected, production ceased after $1.37 \mathrm{cc}$ pore volume of the slug has been injected (Table 6). When 1.37 pore volume of conc. 1 bio-surfactant had been injected, $51.9 \%$ of the initial oil in place was recovered which shows superior improvement on the conventional waterflooding that recovered $29.5 \%$ and further buttresses the efficiency of microscopic displacement to sweep efficiency.

The same process of core restoration was carried out after each flooding and new slug was introduced. For a $10 \mathrm{~g} / 500 \mathrm{~mL}$ bio-surfactant solution, recovery started at about 5 min, with about $7.89 \%$ of residual oil recovered and oil production reached a plateau at around $15 \mathrm{~min}$ after which total recovery was $54.21 \%$ (Fig. 3). For $15 \mathrm{~g} / 500 \mathrm{~mL}$, oil recovery started about 5 min, of which $6.32 \%$ of the residual oil was recovered and peaked at about $15 \mathrm{~min}$ with total cumulative recovery of around $29.4 \%$ (Fig. 4). From Figs. 4, it can be observed that the formulated biosurfactant solutions were able to recover more residual oil than the conventional waterflooding with optimum concentration observed to be between 5 and $10 \mathrm{~g} / 500 \mathrm{~mL}$. The 
5-10 g/500 mL concentrations demonstrate better recoveries because bio-surfactant when present at low concentration in a system, has the property of adsorbing onto the surfaces or interfaces of the system and altering to a noticeable magnitude the interfacial free energies of those surfaces (or interfaces). This interfacial free energy is the difference in nature between the trapped residual oil and the injected surfactants. The higher the dissimilarity in their natures, the greater the boundary tension between them. And of course, the essence of dissolving surfactants into aqueous water is to achieve complete miscibility between the injected fluid and the residual oil. During enhanced oil recovery using a biosurfactant solution, the outer boundary of the injected fluid which is predominantly hydrophobic clings onto the outer boundary of the trapped oil, upon contact, and decreases the dissimilarity between the injected bio-surfactant and the trapped oil. This decrease in the dissimilarity between the two phases contacting each other at the interface is responsible for the improved oil recovery which in other words refers to as a reduction in interfacial tension.

This was further ascertained from the results of core flooding on core B (Figs. 5, 6, Table 7). The results affirmed the potential of bio-surfactant produced from neem seed oil as a possible alternative to the chemical surfactant used in enhanced oil recovery. As stated by Sibanda et al. (2015), there is a direct relationship between surfactant $\mathrm{pH}$ and its washing tendency, that is, its ability to breakdown the boundary forces between two immiscible liquids (in this case residual oil and bio-surfactant slugs). The higher the $\mathrm{pH}$ value the stronger the ability of the surfactant to wash off the oil from the rock interface. The improved oil recovery exhibited by the bio-surfactant slugs can be also be attributed to their $\mathrm{pH}$ values. However, this $\mathrm{pH}$ value can be controlled with respect to the means of synthesizing the surfactant.
Statistical analysis of the percentage recovery after waterflood for the three (3) bio-surfactant concentrations used terms of mean absolute deviation was computed to show the significance of the incremental oil achieved. The mean absolute deviation for core A and B which is an average of absolute differences between the recovery from each concentration of the bio-surfactant and the conventional waterflood was found to be 67.57 and 16.38 respectively which indicate significant amount of residual oil was recovered after waterflood.

\section{Recovery simulation}

On the basis of the results from the core flooding analyzes, a simple box model reservoir simulation study was built to describe the recovery process. The simulation was done to determine the bio-surfactant's performances against conventional waterflooding and primary recovery, that is, the relationship between bio-surfactant concentrations and well oil produced total (WOPT) and well water-cut (WWCT). Figure 7 shows the different oil production from different production scenarios. The cumulative productions are presented in Table 8 . The results show a progressive increase in oil production from natural production to waterflooding and improved production during bio-surfactant slugs injection. Figures 7 and 8 show the plots of oil production against respective water cuts at different production time. The water cuts experienced for surfactant flooding is about $0.91 \%$. The reason for this is owing to well placements which are closer to the water oil contact. Irrespective of this water cuts, oil production increased over waterflooding.

The simulation results show that bio-surfactant flooding at $5-10 \mathrm{~g} / 500 \mathrm{~mL}$ demonstrates the best recovery in terms of well oil produced total between $67,456.7$ and $66,924.3$

Table 7 Production of residual oil using ordinary waterflood and bio-surfactant solutions on core B

\begin{tabular}{|c|c|c|c|c|c|c|c|c|}
\hline \multirow[b]{2}{*}{$\begin{array}{l}\text { Pore Volume } \\
\text { Injected }\end{array}$} & \multicolumn{2}{|l|}{ Waterflood } & \multicolumn{2}{|l|}{ Conc. 1} & \multicolumn{2}{|l|}{ Conc. 2} & \multicolumn{2}{|l|}{ Conc. 3} \\
\hline & $\begin{array}{l}\text { Volume of } \\
\text { oil recovered/ } \\
\text { time (cc) }\end{array}$ & $\begin{array}{l}\text { Volume of } \\
\text { water recov- } \\
\text { ered/time (cc) }\end{array}$ & $\begin{array}{l}\text { Volume of } \\
\text { oil recovered/ } \\
\text { time (cc) }\end{array}$ & $\begin{array}{l}\text { Volume of } \\
\text { water recov- } \\
\text { ered/time (cc) }\end{array}$ & $\begin{array}{l}\text { Volume of } \\
\text { oil recovered/ } \\
\text { time }(\mathrm{cc})\end{array}$ & $\begin{array}{l}\text { Volume of } \\
\text { water recov- } \\
\text { ered/time (cc) }\end{array}$ & $\begin{array}{l}\text { Volume of } \\
\text { oil recovered/ } \\
\text { time (cc) }\end{array}$ & $\begin{array}{l}\text { Volume of } \\
\text { water recov- } \\
\text { ered/time (cc) }\end{array}$ \\
\hline 0 & 0 & 0 & 0 & 0 & 0 & 0 & 0 & 0 \\
\hline 0.432692 & 0.2 & 0 & 0 & 0 & 1 & 0 & 0 & 0 \\
\hline 0.721154 & 2.3 & 0 & 0.2 & 0 & 0.3 & 0 & 0.5 & 0 \\
\hline 1.153846 & 1.52 & 5.8 & 3 & 0 & 0.6 & 0.8 & 0.5 & 1 \\
\hline 1.442308 & 0.08 & 12.6 & 2 & 5.1 & 1.4 & 2.3 & 0.15 & 5.6 \\
\hline 1.730769 & 0 & 22.9 & 0 & 10.3 & 0.3 & 8.9 & 0.35 & 10.2 \\
\hline 2.163462 & 0 & 27.1 & 0 & 13.7 & 1.5 & 19.4 & 1.7 & 21 \\
\hline 2.596154 & 0 & 32.1 & 0 & 23.1 & 1.2 & 25.5 & 1.1 & 26.7 \\
\hline 2.884615 & 0 & 35.3 & 0 & 26.7 & 0 & 28.9 & 0.42 & 29.1 \\
\hline 3.317308 & 0 & 35.5 & 0 & 29.1 & 0 & 32.2 & 0 & 32.3 \\
\hline Total & 4.1 & & 5.2 & & 6.3 & & 4.72 & \\
\hline
\end{tabular}




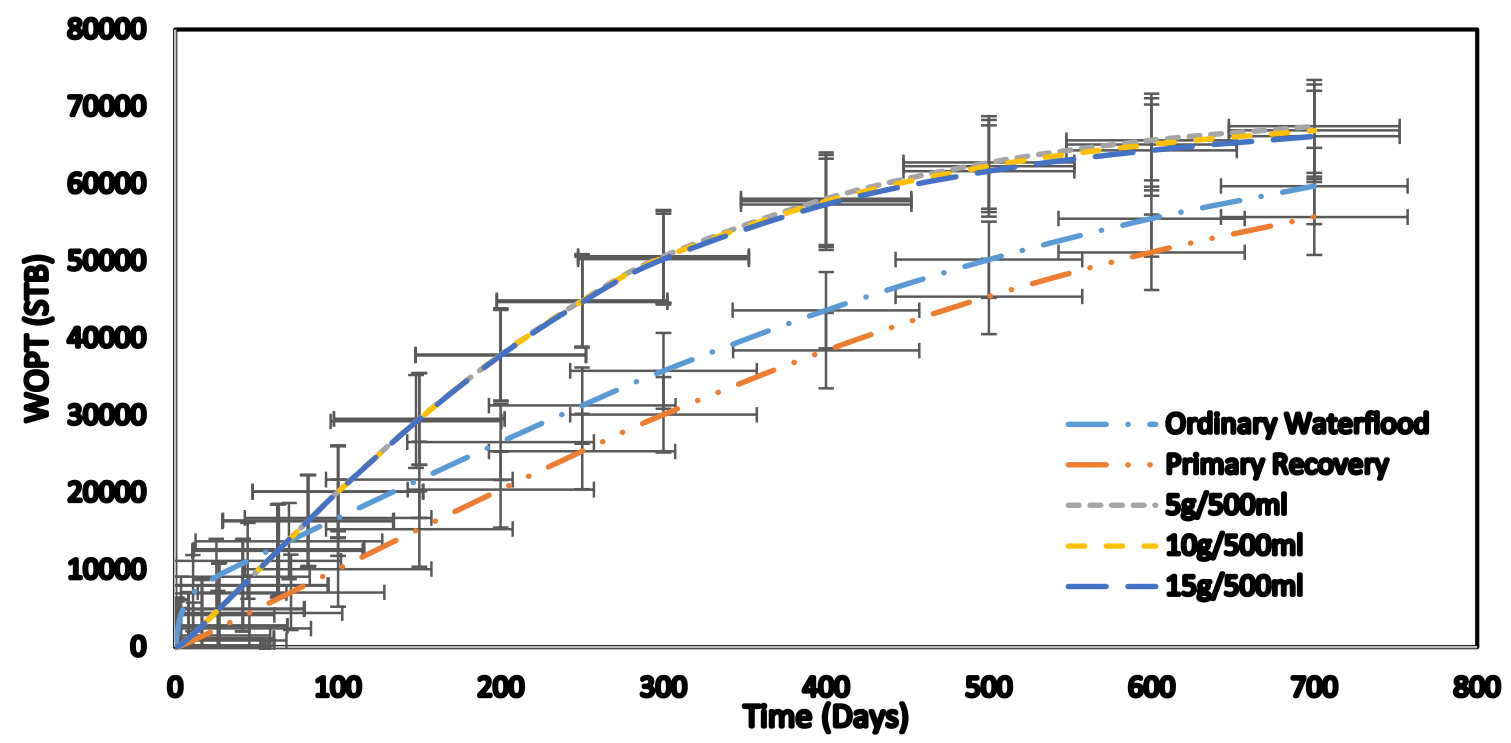

Fig. 7 Well oil produced total against time for different recovery schemes

Table 8 Production summary

\begin{tabular}{lccccc}
\hline Recovery schemes & Primary recovery & Ordinary waterflood & $5 \mathrm{~g} / 500 \mathrm{~mL}$ & $10 \mathrm{~g} / 500 \mathrm{~mL}$ & $15 \mathrm{~g} / 500 \mathrm{~mL}$ \\
\hline WOPT (stb) & $55,712.4$ & $59,730.2$ & $67,456.7$ & $66,924.3$ & $66,164.6$ \\
WWCT & 0.55 & 0.58 & 0.91 & 0.91 & 0.91 \\
\hline
\end{tabular}

stb (Table 8). This further buttresses the role of enhancing oil recovery using the formulated bio-surfactant, and that soap washing effects of the formulated surfactant reduce with the increase in surfactant concentration. The optimum production of $67,456.7 \mathrm{stb}$ was recovered at bio-surfactant slug injection of $5 \mathrm{~g} / 500 \mathrm{~mL}$, which improved oil recovery by $21 \%$ of the total amount recovered by primary recovery compared with $7 \%$ recovered by conventional waterflood. The explanation to this is a lower surfactant concentration for this particular model yielded the highest oil production.

\section{Conclusion}

In this study, the synthesis of surfactant using microbes and non-edible seed oil as substrates was attempted. The potential of this synthesized bio-surfactant for enhanced oil recovery applications from sandstone core samples by surfactant flooding method was evaluated. Surfactant flooding is a popular enhanced oil recovery method. In the experiment, the surfactants help achieve microscopic displacement by reducing the interfacial tension between the trapped oil and bio-surfactant slugs, where they contact the small pockets of trapped residual oil and subsequently mobilizes them. The environmental adverse effects of chemically synthesized surfactants can be overcome by using non-edible seed oil as substrates in bio-surfactants formulation. This work investigated the performance of bio-surfactant produced from non-edible seed oil (neem seed) in enhanced oil recovery applications. Additionally, the adsorption of these biologically synthesized surfactants onto the rock surface that was not investigated in this current work is an area of further research. Likewise, simultaneous flooding of both surfactant and water can equally be explored.

The results indicate that the produced bio-surfactants have promising potentials for recovery of medium to heavy oil. The following conclusions can be drawn:

1. The effectiveness of biologically synthesized surfactants from natural non-edible seed oil has been investigated for application in enhanced oil recovery.

2. The bio-surfactant solutions were able to recover oil better than conventional waterflooding.

3. Optimum bio-surfactant concentration was observed to be between 5 and $10 \mathrm{~g}$ of surfactant per $500 \mathrm{~mL}$ of water.

4. Flooding experiments show incremental recoveries of $51.9 \%, 53.2 \%, 29.5 \%$ for surfactant solutions of 5,10 , 

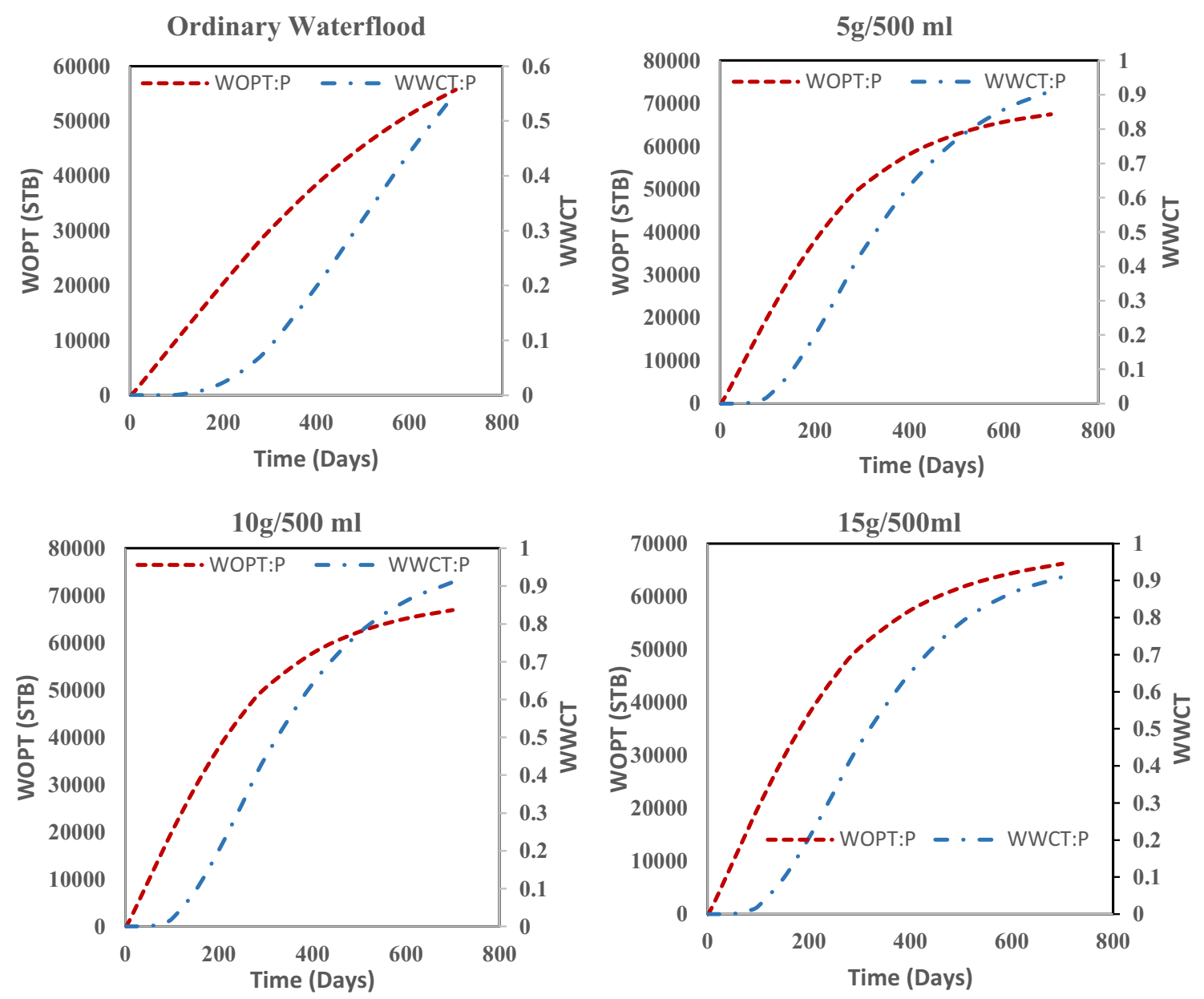

Fig. 8 Well oil produced total and water-cut against time for different recovery schemes

and $15 \mathrm{~g} / 500 \mathrm{~mL}$ and $24.7 \%, 28.7 \%$ and 20.1 for surfactant solutions of 5,10 , and $15 \mathrm{~g} / 500 \mathrm{~mL}$ for cores $\mathrm{A}$ and $\mathrm{B}$, respectively.

Acknowledgements The authors would like to thank Covenant University Centre for Research Innovation and Discovery Ota, Nigeria, for its support in making the publication of this research possible.

Open Access This article is licensed under a Creative Commons Attribution 4.0 International License, which permits use, sharing, adaptation, distribution and reproduction in any medium or format, as long as you give appropriate credit to the original author(s) and the source, provide a link to the Creative Commons licence, and indicate if changes were made. The images or other third party material in this article are included in the article's Creative Commons licence, unless indicated otherwise in a credit line to the material. If material is not included in the article's Creative Commons licence and your intended use is not permitted by statutory regulation or exceeds the permitted use, you will need to obtain permission directly from the copyright holder. To view a copy of this licence, visit http://creativecommons.org/licenses/by/4.0/.

\section{References}

Al-Bahry SN, Al-Wahaibi YM, Elshafie AE, Al-Bemani AS, Joshi SJ, Al- Makhmari HS, Al-Sulaimani HS (2013) Bio-surfactant production by Bacillus subtilis B2O using date molasses and its possible application in enhanced oil recovery. Int Biodeterior Biodegrad 81:141-146

Al-Sulaimani H, Joshi S, Al-Wahaibi Y, Al-Bahry S, Elshafie A, AlBemani A (2011) Microbial biotechnology for enhancing oil recovery: current developments and future prospects. Biotechnol Bioinform Bioeng 1:147-158

Al-Sulaimani H, Al-Wahaibi Y, Al-Bahry S, Elshafie A, Al-Bemani A, Joshi S (2012) Residual-oil recovery through injection of biosurfactant, chemical surfactant, and mixtures of both under reservoir temperatures: induced-wettability and interfacial tension effects. SPE Reserv Eval Eng 15:210-217

Al-Wahaibi Y, Joshi S, Al-Bahry S, Elshafie A, Al-Bemani A, Shibulal B (2014) Bio-surfactant production by Bacillus subtilis B30 and its application in enhancing oil recovery. Colloids Surf B 114:324-333

Banat IM (1995) Bio-surfactants production and possible uses in microbial enhanced oil recovery and oil pollution remediation: a review. Bioresour Technol 51:1-12

Batista RM, Rufino RD, Luna JM, Souza JEG, Sarubbo LA (2010) Effect of medium components on the production of a 
bio-surfactant from Candida tropicalis applied to the removal of hydrophobic contaminants in soil. Water Environ Res 82:418-425

Bordoloi NK, Konwar BK (2008) Microbial surfactant-enhanced mineral oil recovery under laboratory conditions. Colloids Surf B 63(1):73-82

Chai L, Zhang F, She Y, Banat IM, Hou D (2015) Impact of a microbial-enhanced oil recovery field trial on microbial communities in a low-temperature heavy oil reservoir. Nat Environ Pollut Technol 14(3):455-462

Chaprão MJ, Ferreira IN, Correa PF, Rufino RD, Luna JM, Silva EJ, Sarubbo LA (2015) Application of bacterial and yeast bio-surfactants for enhanced removal and biodegradation of motor oil from contaminated sand. Electron J Biotechnol 18(6):471-479

David TE (2019) Formulation of bio-waste derived polymer and its application in enhanced oil recovery. A research project submitted in partial fulfilment of the requirements for the award of Bachelor of Engineering Degree, B.ENG (Hons.) in Petroleum Engineering. Covenant University, Ota. Nigeria

Demirbas A (2008) Comparison of transesterification methods for production of biodiesel from vegetable oils and fats. Energy Convers Manag 49(1):125-130

Desai JD, Banat IM (1997) Microbial production of surfactants and their commercial potential. Microbiol Mol Biol Rev 61:47-64

Fadairo A, Adeyemi G, Ogunkunle T, Oladepo A (2018) Suitability of jatropha biodiesel as a surfactant in steam recovery of Nigeria Tar Sands. J Pet Coal 60(3):542-547

Fadairo A, Adeyemi G, Obioma O, Adedapo A (2019) Formulation of bio-waste derived polymer and its application in enhanced oil recovery. In: SPE Nigerian annual international conference and exhibition, Lagos, Aug 2019

Gao CH, Zekri A (2011) Applications of microbial-enhanced oil recovery technology in the past decade. Energy Sour Part A 33:972-989

Gao P, Li G, Li Y, Li Y, Tian H, Wang Y, Zhou J, Ma T (2016) An exogenous surfactant-producing Bacillus subtilis facilitates indigenous microbial enhanced oil recovery. Front Microbiol 7:186

Geetha SJ, Banat IM, Joshi SJ (2018) Bio-surfactants: production and potential applications in microbial enhanced oil recovery (MEOR). Biocatal Agric Biotechnol 14:23-32

George S, Jayachandran K (2009) Analysis of rhamnolipid bio-surfactants produced through submerged fermentation using orange fruit peelings as sole carbon source. Appl Biochem Biotechnol 158(3):694-705

Gusmão CAB, Rufino RD, Sarubbo LA (2010) Laboratory production and characterization of a new bio-surfactant from Candida glabrata UCP1002 cultivated in vegetable fat waste applied to the removal of hydrophobic contaminant. World J Microbiol Biotechnol 26:1683-1692

Hadj-Kali MK, Al-khidir KE, Wazeer I, El-blidi L, Mulyono S, AlNashef IM (2015) Application of deep eutectic solvents and their individual constituents as surfactants for enhanced oil recovery. Colloids Surf A 487:221-231

Nwobi BE, Ofoegbu O, Adesina OB (2006) Extraction and qualitative assessment of African sweet orange seed oil. Afr J Food Agric Nutr Dev 6(2):1-11

Ojo T, Fadairo A (2017) Effect of jatropha bio-surfactant on residual oil during enhanced oil recovery process. Int J Appl Eng Res 12(20): 10036-10042

Oladepo DA, Ako C, Fadairo AS, Ogunkunle T (2017) Evaluation of different wag optimization and secondary recovery techniques in a stratified reservoir. Int J Appl Eng Res 12(20):9259-9270

Pereira JF, Gudiña EJ, Costa R, Vitorino R, Teixeira JA, Coutinho JA, Rodrigues LR (2013) Optimization and characterization of bio-surfactant production by Bacillus subtilis isolates towards microbial enhanced oil recovery applications. Fuel 111:259-268

Sandersen SB, Stenby EH, von Solms N (2012) The effect of pressure on the phase behavior of surfactant systems: an experimental study. Colloids Surf A 415:159-166

Saxena N, Nilanjan P, Swapan D, Mandal A (2017) Characterizations of surfactant synthesized from palm oil and its application in enhanced oil recovery. J Taiwan Inst Chem Eng 81:343-355

Sibanda NR, Nyathi JA, Ndlovu LN (2015) Chemical properties of jatropha soap and its effects on reactive dyed cotton fabrics as compared to commercial soaps. Zimbabwe J Sci Technol 8:1-9

Torres L, Moctezuma A, Avendano RJ, Munoz A, Gracida J (2011) Comparison of bio- and synthetic surfactants for EOR. J Pet Sci Eng 76:6-11

Tunio SQ, Tunio AH, Ghirano NA, Adawy ZM (2011) Comparison of different Enhanced Oil recovery techniques for better oil productivity. Int J Appl Sci Technol 1(5):143-153

Publisher's Note Springer Nature remains neutral with regard to jurisdictional claims in published maps and institutional affiliations. 